\title{
THE INTERNATIONAL UNIFICATION OF AIR LAW
}

\author{
PETER H. SAND*
}

\section{INTRODUCTION}

On May 3, 1928, Secretary of State Frank B. Kellogg submitted a recommendation to President Coolidge that Congress be requested to authorize an annual appropriation of not more than $\$ 250$ to meet the share of the United States for the expenses of a group called "International Technical Committee of Aerial Legal Experts," more commonly known by its French initials CITEJA. ${ }^{1}$ The request took almost three years to pass the Senate; the date of presidential approval (February I4, 1931) ${ }^{2}$ may be considered as the first official U.S. recognition of the unification movement in air law.

The United States has come a long way since, and now plays a leading part in the work of CITEJA's successor, the Legal Committee of the International Civil Aviation Organization. ${ }^{3}$ The fact remains, though, that due to an earlier isolationist attitude towards international unification Americans were unable to influence the basic conventions which today are the cornerstones of uniform private air law. ${ }^{1}$ The United States had to accept as a fait accompli what were essentially European concepts of codification, and regardless of the praise such "admirable self-denial" won her from European jurists, ${ }^{5}$ this continues to cause a considerable amount of frustration with international efforts towards further unification, and with domestic acceptance of uniform air law in North America.

The international unification of air law, which is generally considered as one

* Referendar 1958, Saarbrücken; D.E.S. 1960, University of Paris; LL.M. 1962, McGill University. Assistant Professor, Institute of Air and Space, McGill University, 1963-65; Visiting Professor, Keio University (Tokyo), 1965-66. Contributor to legal and sociological journals.

${ }_{1}$ Comité International Technique d'Experts Juridiques Aériens (CITEJA), established by the First International Conference on Private Air Law (Paris 1925), at which the United States was represented by

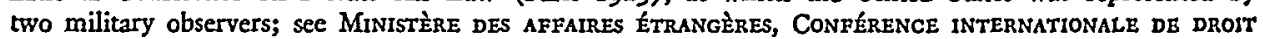
PRIVÉ AÉRIEN I925 (I936). From I925 until r947, a total of 39 countries participated in the works of CITEJA; see Wilberforce, The International Technical Committee of Experts in Air Latw, I INT'L L.Q. 498 (I947).

${ }_{4} 6$ Stat. I162, c. I89, Feb. I4, I93I; see Ide, The History and Accomplishments of the International Technical Committee of Aerial Legal Experts (C.I.T.E.J.A.), 3 J. Air L. 27 (1932), at 42.

${ }^{3}$ See Latchford, Coordination of CITEJA with the New International Civil Aviation Organization, 12 Dep'T State Bull. 3 Io (I945); Latchford, CITE/A and the Legal Committee of ICAO, I7 Dep'T StATE BuLI. 487 (1947); Draper, Transition from CITEIA to the Legal Committee of ICAO, 42 AM. J. INT'L L. 155 (1948).

Not until the chairman of the U.S. delegation to the I933 Rome Conference reported how strongly all delegations were influenced by the work of CITEJA did American representatives attend all working sessions of the committee (from September I935 on). They were handicapped, though, by the fact that French was the only official language of CITEJA; see Report of tHE AMERIcan DeLEGATION TO THE Secretary of State: Fourth International Conference on Private Air Law, Brussels, September 1938, at 33 (Dep't State Pub. No. I40I, 1939).

See Riese, Aktuelle Betrachtungen zur internationalen Vereinheillichung des Luftrechts, I ZeIrscHRIrT FüR LUFTRECHT 29, at 33 (1952). 
of the most advanced and most successful instances of uniform private law, may provide some useful illustrations of both the blessings and the pitfalls of unification.

\section{The Growth of Unificatron}

The success of uniform law in international aviation may be ascribed partly to its environment-the "milieu aérien" - and partly to the historical accident that the beginnings of air law-"last-born of judicial notions" -almost coincided with the beginnings of the international unification of private law in general.

\section{A. Conflicts and Uniform Law}

For reasons inherent in any instrument of communication, but maximized in the most rapid and least land-locked means of transport, aviation tends to generate transnational fact situations of unprecedented multitude and variety. As a result, legal transactions containing one or more "foreign elements" have become the rule rather than the exception, thus providing what has been understated as "a potentially rich source of situations involving a conflict of laws."

One way of dealing with conflicts is to solve them by means of choice of law, the classical method of private international law. In the United States, where conflicts arising from interstate aviation are traditionally solved by attributing each case to the "applicable" or "governing" local law, this method accomplished a satisfactory harmony of case law based on common constitutional principles (including full faith and credit), a common procedural structure (a coordinated court system operated by a homogeneous legal profession), and-at least until recently-a certain conceptual uniformity regarding conflicts of laws. ${ }^{9}$

None of these conditions existed on the international level. Attempts at creating uniform conflicts rules in international air law usually met with the objection that they were inferior to, and might even preclude, substantive unification; ${ }^{10}$ examples are the 1940 Montevideo Treaty ${ }^{11}$ and the 1948 Geneva Convention. ${ }^{12}$ If any uni-

'Lemoine, Des principes et méthodes dans le droit aérien international, 4 Revue françaISE DE DROIT AÉRIEN II5 (1950).

${ }^{7}$ Marcel le Goff, The Present State of Air Law 24 (1950).

${ }^{8}$ Arnold Duncan McNair, The Law of the Air 149 (2d ed. 1953).

'E.g., application of the Restatement's "lex loci delicti" dogma (REstatenent, Conflict of Laws 5378 (I934) to aviation; but see the recent breakdown of the dogma, note 149 infra.

${ }_{10}$ The original terms of reference of CITEJA (note I supra) included elaboration of uniform choiceof-law rules (advocated by A. de La Pradelle); but see Blanc, La portée de l'application des lois nationales dans les premières conventions internationales de droit privé aérien, 5 REVUE GÉNÉRALE DE DROIT AERIEN 386 (1936); and the comments by W. Wengler, on the new I.D.I. draft (note 148 infra), 49 Annuaire de I'Institut de Droit International pt. 2332 (Ig6I).

${ }_{11}$ Treaty on the Law of International Commercial Navigation (of March I9, I940), applicable to air transport (article 43), and subjecting all contracts of international carriage to the law of the place of destination (article 26); 8 Manley O. Hudson, International Legislation 467 (I94I). The treaty has been ratified by 6 South American states, 2 of which are also members of the I929 Warsaw Convention (note $4 \mathrm{r}$ infra).

${ }^{13}$ Convention on the International Recognition of Rights in Aircraft (of June 25, 1948), ICAO-Doc. 
form trend may be deduced at all from the private international law of different states dealing with aviation, ${ }^{13}$ it is what Arthur Nussbaum called the "homeward trend" (Heimwärtsstreben) of the courts towards their lex fori, i.e., "a tendency to arrive, if possible, at the application of domestic law."14 Some would ascribe this to the judges' plain ignorance of foreign air law, ${ }^{15}$ but it may indeed be questioned whether the application of some exotic foreign law, as in the Ooievaar case, ${ }^{18}$ is a less inappropriate solution. The very method of choice of law, no matter which local law eventually "governs," creates a degree of unpredictability which is intolerable in world air transport, ${ }^{17}$ if only for its impact on insurance costs.

Another way of dealing with conflicts is to avoid them. The first to realize this useful method was, of course, the air transport industry, and along with the earliest international air routes it developed standard conditions of carriage to predetermine the applicable law. A famous example were the Antwerp conditions of the International Air Traffic Association (IATA) ${ }^{18}$ which stipulated, inter alia, that actions had to be brought at the carrier's principal place of business and that the national law of that forum applied. ${ }^{10}$ When it turned out, however, that this preventive clause was clearly disapproved by British, American, and European law, ${ }^{20}$ the clause had to be dropped from the postwar IATA conditions. ${ }^{21}$ This illustrates

$76_{20}$, subjecting the validity of security rights to the law of the place of aircraft registry (law of the flag), with certain exceptions for the lex rei sitae; see note 42 infra.

${ }^{13}$ E.g., the law applicable to contracts of carriage by air is the law of the flag according to article Io of the Italian Codice della navigazione (1942); but the law of the place of contracting according to article 36 of the Austrian Allgemeines Bürgerliches Gesezzbuch (1811), see Gonano v. British European Airways, Sup. Ct. of Austria (Oct. 5, 1955), to Österreichische JuRIstenzeitung 672 (1955), with note by Stanzl.

14 Arthur Nussbaum, Principles of Private Internationat Law 37 (1943); $c$. Ehrenzweig, The Lex Fori in the Conflict of Laws: Exception or Rule?, 32 Rocky MT. L. Rev. 13, 14 (1959).

${ }^{18}$ Knauth, Air Carrier's Liability in Comparative Law, 7 ArR L. REv. 259 (1936), quoting Lord Stowell's memorable words in The Johan \& Siegmund, [1810] Edw. 242, x65 Eng. Rep. 1096 (Ecc. Adm. P. \& D. I810): ". . . what may be the law of Hamburgh, I cannnot tell . ..."

${ }^{16}$ Young and Baudart v. KLM, Supreme Ct. of the Netherlands (Civ. Ch., March 18, 1938), [1939] Nederlandse Jurisprudentie Ir3 (note Meijers); applying Siamese law to the wrongful death of a Frenchman on a Dutch airliner near Bangkok (Thailand), and thereby validating a contract that would have been void under the lex fori. See also Van Gorkum, De clausules betreffende uitsliniting van aansprakelijkheid, [1939] RechrsGeleERd MAgAzijn TheMis I52, at 157.

${ }^{17}$ Ripert, L'unification du droit aérien, I REvUE GENERALE DE DROIT AERIEN 25I, at 257-258 (I932).

${ }^{18}$ Founded at The Hague in 1919, re-established in 1945 as "International Air Transport Association" incorporated in Montreal (20th Parl., 9 Geo. 6, Ist Sess., 1945), and defined by the U.S. Civil Aeronautics Board as "an all-embracing international cartel"; see Antitrust Subcommittee of House Committec on the Judiciary, Report on Airlines, 85th Cong., xst Sess. 234 (1957).

${ }^{10}$ Clause 22, para. 4(I) of the uniform conditions for the carriage of passengers, and clause $2 \pi$, para. $4(x)$ of the conditions for the carriage of goods; see CHristopher N. Shuwcross \& Kerru $M$. BEAUMONT, ON AIr LAw II5I (2d ed. 195I), and Döring, Die Neugestaltung des Luffbeförderungsvertrags im europäischen Luffverkehr, 2 ARCHIV FüR LuFTrecht I, at 5 (1932).

${ }^{20}$ See Kidston v. Lufthansa (C.A., Oct. I4, I936), [1938] I Lloyd's List L.R. I, 2; U.S. Civil Aeronautics Board, Order E-1590 (May I8, 1948), and Ehrenzweig, Adhesion Contracts in the Confict of Laws, 53 Colum. L. Rev. I072, i090 (r953); Maurice Lemoine, Traité de droit á́rien 402 (1947), and Otto Riese \& JEAN T. LAcour, Précis de dRoit á́rien international et suisse 223 (195I).

${ }_{21}$ See IATA Manual of Traffic Conference Resolutions, Series 275(b) and 600(b); Gazdik, The Net Contract Between Air Carriers and Passengers, 24 J. Arr L. \& CoM. 151, 158 (1957). 
one major defect of so-called "private unification of air law": Uniform standard contracts, even government-approved IATA tariffs, are at the mercy of national lawmakers and run a fair risk of being thrown out of court. ${ }^{22}$

There remains a third way of dealing with conflicts: to avert them before they actually arise, by means of international unification of air law. If the law is substantially the same no matter where the aircraft flies or crashes, the problem of choice of law ceases to be relevant. Air carriers, aircraft users, and potential aircraft victims will be able to predict and to calculate their risks with a maximum of certainty. ${ }^{23}$ To the medical analogies drawn by Melvin G. Shimm and Clive M. Schmitthoff-"clinical approach" (i.e., conflict resolution by judicial choice-of-law) vs. "preventive approach" (i.e., conflict avoidance by professional lawyership) ${ }^{24}$-we may add another recent weapon of medical science: eradication of the disease itself; i.e., applied to law, conflict removal by legislative unification.

Unification is conceivable on three levels: national, regional, and universal. On a national scale, uniform air legislation was attempted in the United States, though with little success. For instance, the 1938 Uniform Aeronautical Liability $\mathrm{Act}^{25}$ was opposed by many aviation interests and failed; ${ }^{26}$ it seems that even its authors did not view unification as necessarily superior to the existing practice of choice of law and mutual recognition in interstate air law. ${ }^{27}$ On a regional level, a certain degree of uniformity by parallel air legislation was accomplished in Scandinavia, ${ }^{28}$ attempted in theory in Latin America, ${ }^{29}$ and in practice in Eastern Europe. ${ }^{30}$ This

32 Clause 3 of the uniform IATA conditions of contract (supra) recognizes the superiority of "laws, government regulations, orders or requirements." E.g., in Robert-Houdin v. Panair do Brasil the Tribunal de Grande Instance de la Seine (July 9, I960) refused to enforce the IATA "delay clause," see 24 Revue géntrate de l'aIr 285 (1961), (note Sundberg); and in Stratton v. Trans Canada Airlines, 32 D.L.R. (2d) 736 ( 1962 ), the Court of Appeals of British Columbia all but ridiculed "Walker's Tariff" invoked by the airline.

28 Riese, supra note 5 , at 40.

${ }^{24}$ Shimm, The Preventive Law of Conflicts: Foreword, 2 I LAw \& ConTEMP. PROB. 427 (1956), and Schmitthoff, Conflict Avoidance in Practice and Theory, id. at 429.

${ }^{85}$ Adopted by the National Conference of Commissioners on Uniform State Laws at Cleveland on July 23, I938, see 9 J. AIr L. 724 (1938). Cf. Knauth, The Uniform State Aeronautical Liability Act, 9 AlR L. REv. 354 ( 1938 ), and Hotchkiss, Changing Standards of Liability Towards Passengers for Owners and Operators of Aircraft, 26 VA. L. REv. 796 (1939).

${ }^{20}$ The Commissioners eventually withdrew their endorsement of the act, while proposals for federal legislation were equally unsuccessful; see Sweeney, Is Special Aviation Liability Legislation Essential?, I9 J. AIR L. \& CoM. I66, 3 I7 (I952).

${ }^{37}$ See the remarks on unification and conflicts law by Knauth, Renvoi and Other Conflicts Problems in Transportation Law, 49 Colum. L. REv. I, 20 (1949).

${ }^{38}$ See Nylen, Scandinavian Co-operation in the Field of Air Legislation, 24 J. AIR L. \& Conk. 36 (1957); Lödrup, Le droit aérien en Scandinavie, 22 RevUe GENérale DE L'AIR 240 (I959); Bahr, Arbeidet med ny luftfartslov, I ARKIV FOR LUFTRETT 2 (1958); and the synoptic multilingual texts in

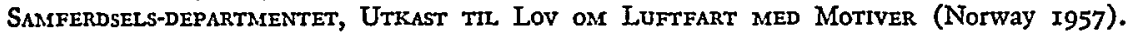

${ }^{30}$ See Paulo E. Tolle, Air Law in Latin Amercia, 2 vols. (thesis McGill, I958); AleJandro BauzA ARAUjo, UNificación LEgISLATIVA, DOCTRINAL $y$ JURISPRUdENCIAL IBEROAMERICANA EN EL DERECHO

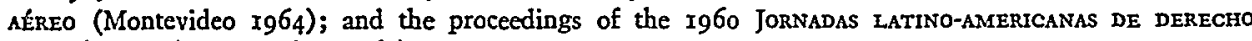
AERONÁUTICO (Buenos Aires 1962).

${ }^{30}$ See Majoros, Fragen des Luftrechts in den sozialistischen Staaten, 5 JAFRBUch Für OsTrEchr I75 (1964); Sand, Die Entwicklung des Luftfahrtrechts in der Sowjetunion, to OSTEUROPA-RECHT 157, at I98-205 (English summary at 206) ( $\mathrm{rg64}_{4}$ ); and Berezowski, Le droit aérien des pays socialistes de l'Europe, I9 REvUE FRANÇAISE DE DROIT aERIEN (forthcoming, I965). 
geographically limited unification, however, is important mainly for matters of public air law; it is not, nor was it designed to be, a substitute for the world-wide unification of private air law which we shall now analyze in more detail.

\section{B. The Present State of Unification}

The institutional framework for the elaboration of uniform air law is provided since 1947 by the International Civil Aviation Organization (ICAO) in Montreal. ${ }^{81}$ Unlike the pre-war CITEJA, the Legal Committee and the permanent Legal Bureau of ICAO also deal with public air law, ${ }^{32}$ and participate in the regulatory process which formerly had been a prerogative of the International Commission for Aerial Navigation (ICAN). ${ }^{33}$ With the continuous involvement of governments in all sectors of civil aviation, a clear-cut theoretical separation of "private air law" has become virtually impossible.

Regulatory activities of ICAO include the standardization of national air regulations ranging from flight signals to air accident investigations, by means of "standards" and "recommended practices" enacted and amended by a quasi-legislative process in the form of Technical Annexes to the 1944 Chicago Convention. ${ }^{84}$ Since all member states are under an obligation to report any deviation from ICAO standards, the uniformity of national law concerning technical rules is under constant control. ${ }^{35}$

For legal matters falling outside the normal regulatory process, ICAO's Legal Committee (composed of delegates appointed by member governments) in biennial sessions elaborates draft conventions on uniform air law, eventually to be submitted to an ad hoc diplomatic conference for final adoption and signature. ${ }^{36}$ Upon ratification, states are bound to enact the uniform text as national law. ${ }^{37}$

Contrary to early historical projects for an all-embracing international "Code

${ }^{31}$ In general see Jacob Schenkman, International Civil Aviation Organization (1955).

${ }^{22}$ See the report by the ICAO Legal Bureau, Methods Followed in the Work of the Unification of Public Air Law, [1956] 2 UNIFication of LaW Yearbook I6r.

${ }^{33}$ Commission Internationale de Navigation Aérienne, established by the Paris Convention (of Oct. $x_{3}$, 19r9); the United States was not a member. See Jochen Erler, The Regulatory Functions of ICAN and ICAO: A Comparative Study (thesis, McGill, I964).

"Article 37, Convention on International Civil Aviation (of Dec. 7, 1944), 15 U.N.T.S. 295; sec Jones, Amending the Chicago Convention and Its Technical Annexes, I6 J. AIR L. \& CoM. 185 (1949); Malintoppi, La fonction normative de l'O.A.C.I., 12 Revue générale de l'Alr I050 (1949); Ros, Le pouvoir législatif international de l'O.A.C.I., I6 RevUe gENERALE de L'AIR 25 (1953); Mankiewicz, L'adoption des annexes à la Convention de Chicago par le Conseil de l'O.A.C.I., in Betrrn̈̈os zum INTERNATIONALEN LUfTRECHT: FESTSCHRIFT Für ALEX MEYer 82 (1954).

${ }^{35}$ See Pépin, ICAO and Other Agencies Dealing with Air Regullation, 19 J. AIR L. \& Com. 152 (1952), and Eugène Pepin, Development of the Nationat Legislation on Aviation Since tuib Carcago Convention (Institute of Air \& Space Law Pub. No. 3, 1957).

${ }^{38}$ For a detailed description of procedures see the report by the ICAO Iegal Bureau, ICAO and the Unification of Private Air Law, [1956] 2 UnIFICATION OF LAW YEARBOOK 199, arranged according to the "stages of unification" outlined by Harald Cooke Gutteridge, Comparative law i45 (2d ed. 1949); for recent innovations see note 179 infra.

${ }_{37}$ r933 Rome Convention (art. I), I948 Geneva Convention (art. XV); $c f$. Chauveau, Conventions

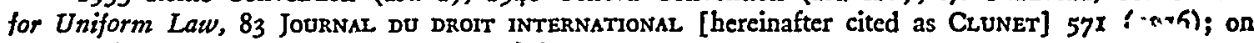
the transformation procedure, see note 73 infra. 
of the Air,"38 the codification of air law proceeded functionally, and step by step. Apart from the 1963 Tokyo Convention on criminal law, ${ }^{39}$ the conventions may be grouped in three main categories of private law, each covering the relations of the air carrier, or aircraft operator, to a particular group of potential adverse interests. ${ }^{\mathbf{4 0}}$

I. Aircraft Users: the rg29 Warsaw Convention for the Unification of Certain Rules Relating to International Carriage by Air (approximately 80 member states), ${ }^{\mathbf{4 1}}$ with the I955 Hague Protocol (44 members) amending, and the Ig6r Guadalajara Convention ( 12 members) supplementing it;

2. Creditors: the $x 933$ Rome Convention for the Unification of Certain Rules Relating to the Precautionary Arrest of Aircraft (I9 members), and the I948 Geneva Convention on the International Recognition of Rights in Aircraft (23 members);

3. Third Parties: the I952 Rome Convention on Damage Caused by Foreign Aircraft to Third Parties on the Surface (I8 members), revising the r933 Rome Convention ( 5 members) with the supplementary 1938 Brussels Insurance Protocol (2 members).

These conventions were designed to unify the liabilities of air carriers and operators, and to standardize international aviation documents (except for the Geneva Convention, which instead of creating a standard security form stipulates a kind of international full-faith-and-credit clause). ${ }^{42}$ Presently on ICAO's program of work are draft conventions on aerial collisions, on the liability of air traffic control agencies, and on liability for nuclear damage in civil aviation. ${ }^{43}$

Most conventions on uniform private air law are limited in scope to certain "transnational" fact situations (flights between different member states, damage by foreign aircraft, and so on), thus aiming at partial, rather than total, unification. ${ }^{44}$ In practice, however, a growing number of states voluntarily extend the scope of uniform air law to include "national" fact situations (cabotage and domestic carriage), or at least to bring domestic legislation in line with the principles of the conventions; ${ }^{45}$ even states which for various reasons did not ratify a convention

\footnotetext{
${ }^{38}$ Discussed as early as 1906 in the Institute of International Law, and particularly in the Comite Juridique International de l'Aviation; see Peter H. SAND, Geoffrey N. Pratt \& James T. Lyon, AN Historical Survey of the LAw of Flight 8 (ig6r).

${ }^{35}$ Convention on Offences and Certain Other Acts Committed on Board Aircraft (of Sept. I4, 1963), ICAO-Doc. 8364 .

10 For a ready collection of texts in English see Shawcross \& BeaUmoNT, op. cit. supra note I9; in French see Nicolas Matésco Matte, Tratte de droit a Érien á́ronautioue (1964).

"As of Jan. 1, 1965; all treaty data used here are based on information received from the Legal Bureau of ICAO, Montreal, for this date. But see notes 56-70 infra, on the difficulties regarding membership records.

'S Supra note i2; see Stojan A. Bayitch, Aircraft Mortgage in the Americas 47 (1960), and Bernard Hofstetter, L'hypothèque aérienne (thesis, Lausanne, 1950).

${ }^{13}$ For details see ICAO-Doc. 8444-LC/ I5I, Annex D, Part A.

"See Lemhöfer, Die Beschränkung der Rechtsvereinheitlichung auf internationale Sachverhalte, 25 RABels Zeitschrift [hereinafter cited as Rabels Z.] 40I, 430 (I960).

${ }^{*}$ See Guinchard, L'infuence de la Convention de Varsovie sur les règles de droit interne relatives à la responsabilité du transporteur aérien, II REVUE FRANÇAISE DE DROIT AÉRIEN I89 (I957).
} 
occasionally use it as a model for their national statutes. ${ }^{40}$ One further extension of uniform air law, the general "Warsaw clause" in international standard contracts of carriage, regrettably has been abandoned by IATA. ${ }^{47}$

As uniform air law not only influenced, but often anticipated and preceded national legislation, traditional differences between legal systems-such as the cliché of "written Continental law vs. judge-made Anglo-Saxon Law"48-lost their former significance. Air passengers traveling anywhere in the United Kingdom, in France, or in the Hungarian People's Republic, today are subject to identical codified law; ;0 $^{40}$ and it is not unusual for European judges to interpret their uniform aviation statutes by reference to English and American precedents. ${ }^{50}$ But this advanced state of unification is not without its problems.

\section{II}

\section{CRIsIs of Growth}

The first "International Conference on Private Air Law" took place in Paris in the fall of $1925 .{ }^{51}$ Today, one generation later, the international unification of air law has reached what Marcel Saporta terms its "crisis of growth":52 not a deadlock or a dramatic failure, but a mounting dissatisfaction. Imperfections, oversights, and contradictions, once viewed "with indulgence, in the light of the beautiful work accomplished on the whole," they begin to obstruct the further progress of uniform air law. Some of the difficulties that have emerged both in operation and in substance may indeed be symptomatic for uniform private law in general.

\section{A. Operational Problems}

Apart from substantive private law, all conventions on uniform air law contain a set of rules relating to the "operational aspects" of international unification.

${ }^{16}$ For certain provisions of the Rome Conventions incorporated in the law of Switzerland, sec Schaerer, L'unification internationale du droit aérien, in CouRs D'INTRODUCTION AU DROIT AERIEN 27,29 (Zürich 1959).

"Since the r949 Bermuda Conditions, "Warsaw rules" apply to "Warsaw fights" only; for all carriage not covered by the Warsaw Convention, special conditions of contract are stipulated which are far more favorable to the carrier. See the critique by Roger SAINT-ALART, LE DROIT AERIEN 151 (I955), and $c f$. Julian G. Gazdik, Analysis of Certain Aspects of the Law of Contracts Relating to International Carriage of Goods by Air, p. 40 (thesis, McGill, 1950).

${ }^{8}$ See Daniel Lureau, la responsabilité du transporteur aerien: Lois nationales at ConVENTION DE VARsovie (Paris r96I), and our book review in I2 AM. J. CoMp. L. II3 (1963).

40 These sample countries, representing different legal systems, all have extended application of the uniform Warsaw model to their domestic air law by special statute (Hungary, 1936; Britain, 1952; France, 1957).

${ }^{50}$ E.g., the Tribunal Civil of Brussels in Fischer v. SABENA (May 6, 1950), 4 REvuE pnuNç1sE DE DROIT AERIEN 4II, 42I (1950), and the Court of Appeal of Paris in Hennessy v. Air France (Feb. 25, I954), 8 REVuE FRANÇAISE dE DROIT AERIEN 45, 65 (r954), citing Anglo-American case law re "wilful misconduct."

5x Supra note $\mathrm{r}$.

62 Saporta, La crise de croissance du droit international aérien, 18 Revue ófNERALE de L'Ain I9I (1955).

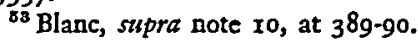


They require a special technique of treaty-making and implementation, developed and determined by diplomatic, constitutional, and judicial practice.

\section{Membership}

As the scope of application of uniform air law often depends on transnational criteria such as "international flights" between member states, ${ }^{54}$ the definition of "High Contracting Parties" is important. All private air law conventions are open treaties, i.e., any state may acquire (or terminate) membership by unilateral act directed to the depositary, or indirectly by "inheritance" from a member state. No approval by other members is required; the nature of the relations between new member, depositary, and old members is undefined.

It is well established-after the grotesque misunderstanding of Philippson $v$. Imperial Airways $5^{55}$-that in order to become members, signatories must deposit an instrument of ratification, and other states, an instrument of adherence (accession). In practice, however, there is utter confusion as to ratifications not recognized because of reservations, ${ }^{56}$ a government not recognized by the depositary, ${ }^{57}$ a depositary government not recognized by some members, ${ }^{58}$ and ratifications recog. nized by the depositary, but not by other members. ${ }^{59}$

Another group of unsettled cases concerns territories which came under the régime of air law conventions not by virtue of their own adherence, but by act of a colonial power, ${ }^{60}$ by annexation, ${ }^{61}$ or by state succession. ${ }^{62}$ In particular, the

ot Article I of the Ig29 Warsaw Convention, described as a "special conflicts rule" (with two contacts, instead of one) by Riese, Zum Warschauer Luftprivatrechtsabkommen, 4 RABEss Z. 244, 260 (1930).

Es Philippson v. Imperial Airways Ltd., [I939] A.C. 332 (H.L.), which prompted the British government to send a diplomatic note to Washington dissociating itself from their lordships' decision; see 4 Green Haywood Hackworth, Digest of International Law 373 (I942), and William W. Bishop, JR., International Law: Cases and Materials 135 (2d ed. I962); but of. Bin Cheng, High Contracting Parties in Air Law: Philippson v. Imperial Airways Revisited, [1959] J. Bus. L. 30.

${ }^{60}$ The United States refused to recognize the Mexican and Chilean ratifications of the 1948 Geneva Convention (supra note I2), see I952 U.S. \& Can. Av. R. 433.

87 The National Chinese Republic (Taiwan) is not considered as a member state of the original Warsaw Convention by the Polish Foreign Ministry as depositary, while its ratification of the supplementary Guadalajara Convention has been deposited with the Mexican Foreign Ministry.

${ }^{88}$ It appears that the Liberian ratification of the 1929 Warsaw Convention was deposited in 1942 , with the Polish exile government in London (then not recognized by the Soviet Union and the Axis).

${ }^{\circ}$ See the U.S. declaration concerning adherence to the Warsaw Convention by the People's Republic of China (Peking), rg60 U.S. \& Can. Av. R., Treaty Data at xii.

${ }^{\circ}$ See Bosquet, L'article 40 de la Convention de Varsovie, [I96I] Revue du secrétariat généraI a L'aviation civile et commerciale I9, and Attias v. Air Afrique, Algiers, Court of Appeal (Dec. 24, I943), 2 REVUE FRANÇAISE DE DROIT AÉRIEN IO7 (I948), dealing with carriage from Algeria to Tunisia.

01 On the situation of Austria after the German "Anschluss" see Ebner, Österreich und das Warschatler Abkommen, I ZEITSCHRIFT FüR VERKEHRSRECHT I49 (I956); but cf. Meyer, Probleme des internationalen und nationalen Schadensersatzrechts der Luftfahrt, I6 VERSICHERUNGS-RUNDSCHAU 265 , 27 I (I96I). Another case is Syria's membership via the United Arab Republic.

es Pakistan: Dabrai v. Air India Ltd., Indian High Court of Bombay (April r7, 1953), 20 INr't L.R. 4 (I953); Lebanon: Gallais v. Aéro-Maritime Co., Tribunal Civil de la Seine (April 28, 1954), 8 REvUE FRANÇAISE DE DROIT Atrien 184 (1954); Laos and Vietnam: Trésor Public v. Aigle Azur Co., Tribunal de Grande Instance de la Seine (February Ist, I960), 88 CuUner I105 (I96r). 
membership status of former colonial territories after their independence demonstrates variations of diplomatic practice approaching chaos ${ }^{63}$ and constantly nourishing litigation. Equally uncertain are the termination of membership by loss of independence, ${ }^{64}$ the legal effects of World War $\mathrm{II}_{9}{ }^{65}$ and the duplication of membership in federal states. ${ }^{66}$

The truth is that for some of the conventions there is presently no reliable record of membership at all. For instance, as regards the Warsaw Convention-by far the most important uniform air law-the "authentic" record published by the Polish Foreign Ministry as depositary lists as individual members, inter alia: Newfoundland besides Canada, the (East) German Democratic Republic besides the German Reich, and Ukrainia besides the Soviet Union. ${ }^{67}$ Several states prefer to publish different membership lists of their own. ${ }^{88}$ The date on which the Hague Protocol was to enter into force (after a required number of thirty ratifications) thus depended on whoever did the counting, and only a diplomatic trick saved uniformity. ${ }^{60}$ As to the list of states which exercised their right under the treaty to exempt governmental carriage from unification, the confusion is universal..$^{70}$

As a result, the drafting of "final clauses" has become a favorite field for diplomats rather than for lawyers. International conferences on private air law are turning into arenas for demagogical battles over "colonial clauses," of treaty depositary is becoming a key for power politics. ${ }^{72}$

${ }^{08}$ Some states declared themselves to be bound ex tunc by ratifications or adherences made on their behalf by the colonial powers; others either withdrew or adhered separately ex nunc; most remained silent. In favor of automatic succession is Mankiewicz, Air Law Conventions and the New States, 29 J. AIr L. \& CoM. 52 (I963); but cf. Shawcross \& BenUmoNt, op. cit. supra note 19, at 39, 340.

os Latvia, an original High Contracting Party of the 1929 Warsaw Convention, now is part of the Soviet Union and disappeared from the member list published by the Polish government; while Newfoundland, now part of Canada, is still listed, see note 67 infra.

${ }^{O E}$ The Federal Republic of Germany formally reactivated the pre-war German membership by an exchange of notes with some former belligerent and neutral states; but cf. SAS v. Wucherpfennig, Landgericht Hamburg (April 6, I955), 4 ZeITschrifT für. LUFTrecht 226 (1955), (note Meyer), which considered the Warsaw Convention as having been tacitly revived between Germany and Italy by mere resumption of mutual air traffic.

${ }^{\circ}$ The Soviet Union ratified the Warsaw Convention in 1934, and the Hague Protocol in 1957; Ukrainia and the Byelorussian Soviet Republic in I959 and in 1960-6I, respectively: see Sand, supra note 30 , at 196 .

or [1963] Dziennik Ustaw No. 33, pos. I90; the ICAO-Secretariat distributes this list in English, as received from Warsaw.

is The most complete one by the British Foreign Office, see Carriage by Air (Parties to Convention) Order, Stat. INSTR., I 962 , No. 2186.

${ }^{\circ 9}$ When the deadline was approaching in 1963 , four Scandinavian states deposited their ratifications simultaneously, thus pushing the number over the 30-mark for all counts.

${ }^{70}$ According to information from ICAO: Canada, Congo (Brazzaville), Ethiopia, Pakistan, and the United States. But cf. 20 J. AlR L. \& CoM. 315 (1953): Japan and Argentina; SHAwcross \& BenUmoNT, op. cit. supra note 19, at 897: Portugal; and the official U.K. list (note 68 supra): the Philippines.

${ }^{71}$ See the debates during the Guadalajara conference; Mrchaes Milde, The Proplems of Lianilities in International Carriage by AIr ro4 (Acta Universitatis Carolinae, Juridica No. 1, 1963). At the 1963 Tokyo conference, a Soviet proposal carried by the Afro-Asian vote "salomonically" eliminated all unpopular references to non-self-governing territories from the text of the convention.

${ }^{72}$ At the 1961 Guadalajara conference a narrow "Western" majority eliminated Poland as depositary for the supplementary convention (article XII), and restricted membership to states belonging to the U.N. or to its specialized agencies (articles XI, XIV). 


\section{Transformation}

Unlike ordinary treaties, the conventions on uniform private air law do not primarily create rights and duties as between nation-states, but raather between air carriers, aircraft users, aircraft victims, and so on- "inter-individual law," to use Georges Scelle's expression. For this purpose they have to be transformed into the law of every land according to local constitutional practice. ${ }^{73}$

In some states the conventions are adopted by mere ratification and publication in the official gazette; ${ }^{74}$ other states require special legislation to enact the uniform law as a parliamentary statute ${ }^{\mathbf{7 5}}$ and in some states, legislative provisions are added to implement and adapt the treaty for the purposes of national law. ${ }^{76}$ In the United States, the Warsaw Convention was originally denied self-executing effect by the courts. ${ }^{77}$ It was later accepted as self-executing but denied a statutory cause of action. ${ }^{78}$

Particular problems arise in federal systems when the international unification of air law touches on matters within state competency. Thus, provisions relating to the enforcement of foreign judgments in the 1952 Rome Convention were opposed by the United States and Canadian delegates as being outside federal jurisdiction; ${ }^{79}$ and the effect of air law conventions on state wrongful death acts and workmen's compensation statutes is still unsolved. ${ }^{80}$

Part of the transformation process is the translation from authentic treaty language into national legal language. There are no less than three different official English translations of the Warsaw Convention (the British, Irish, and American

\footnotetext{
${ }^{73}$ See Seidl-Hohenveldern, Transformation or Adoption of International Law into Municipal Law, I2 INT'L \& CoMP. L.Q. 88 (Ig63).

"E.g., see Erades, Promulgation and Publication of International Agreements and Their Internally Binding Force in the Netherlands, in Varia Juris Gentium: Liber Amicorum For J. P. Adrien François 93 (1959); Dehaussy, Les conditions d'application des normes conventionnelles sur le for interne français, 87 CLUNET 702 (1960); Level, La publication en tant que condition d'application des traités par les tribunaux nationaux, 50 REVUE CRITIQUE DE DROIT INTERNATIONAL PRIVte [hereinafter cited as REv. CR. DR. INr'L PR.] 83 (196r).

${ }^{75}$ Compare the enactment of the Warsaw Convention in the United Kingdom Carriage by Air Act, (I932) 22 \& 23 Geo. 5, c.36; Irish Air Navigation and Transport Act No. 40 (1936); Canadian Carriage by Air Act, (I952) Rev. Stat. c.45. See James Leslie Brierly, The Law of Nations 86 (5th ed.

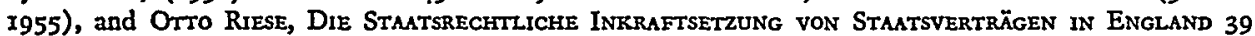
(1929).

To E.g., the German act implementing the Warsaw Convention: DuRchFüHRUNGsGESETz zUM Warschauer AbKommen, of Dec. 15, 1933, [I933] I Reichis-Gesetzblatt 1079.

${ }^{77}$ See 49 Stat. 3000 (1934), as interpreted in Choy v. Pan American Airways, Inc., I94I Am. Mar. Cas. 483 (S.D.N.Y.), 1942 U.S. Av. R. 93, 98; and in Wyman v. Pan American Airways, Inc., 181 Misc. 963,43 N.Y.S.2d 420 (Sup. Ct. I943), I943 U.S. Av. R. I, $4 \cdot$

${ }^{78}$ Indemnity Insurance Co. v. Pan American Airways, Inc., 58 F. Supp. 338 (S.D.N.Y. I944), I945 U.S. Av. R. 52, 54; Noel v. Linea Aeropostal Venezolana, I44 F. Supp. 359 (S.D.N.Y. r957), 1957 U.S. \& Can. Av. R. 274.

${ }^{70}$ See Brown, The Rome Conventions of 1933 and 1952: Do They Point a Moral?, 28 J. ArR L. \& CoM. $418,434(196 \mathrm{I}-62)$.

${ }^{80}$ See Rosevear, Wrongful Death Actions Under the Canadian Carriage by Air Act, 37 CAN. B. REv. 216 (1960); and the ensuing correspondence with Alastair Paterson, id. at 635, and 38 CAN. B. REv. I53, 156 (Ig6r).
} 
versions), ${ }^{81}$ at least three official Spanish versions (Spain, Mexico and Argentina); and while there was only one German translation of the original 1929 treaty, the Ig6I Guadalajara supplement now exists in a West-German, an Austro-German and a Swiss-German version. ${ }^{82}$ Although reference to the authentic French text (article 36 of the Warsaw Convention) may help to solve diplomatic conflicts of interpretation as between member states, it seems doubtful whether a foreign language can in practice be made the yard-stick of interpretation as between ordinary citizens, too. ${ }^{83}$

Once it is transformed, uniform air law is on equal level with statutory law, and not as Paul Chauveau contends, immune against subsequent legislative action. ${ }^{84}$ There is no international authority to control or prevent implementing legislation, just as there is nobody to verify or standardize national translations, "authoritative" interpretations, ${ }^{85}$ and even less, judicial application of the (once) uniform law. The situation perfectly illustrates what Franz Kahn described as "latent conflict of laws." 86

\section{Interpretation}

Recent surveys of the judicial interpretation of the Warsaw Convention in various member states ${ }^{87}$ confirm a pessimistic forecast voiced in $1927:^{88}$ In the absence of

${ }^{81}$ On the discrepancies see I934 U.S. Av. R. 245; 26 J. AIR L. \& CoM. 260 (I959); and Sirawcross \& Beatomont, op. cit. supra note 19 , at $83(\mathrm{~g})$. According to Holzer Watch Co. v. Seaboard \& Western Airlines (N.Y. City Ct., Sept. 30, 1957), 1958 U.S. \& Can. Av. R. 142, American courts are bound by the American text "without regard to the British translation."

82 The joint translation of the 1929 Warsaw Convention was the result of a meeting of the three German-speaking delegations at Budapest in 2930 . At the 1962 joint meeting in Berne, howcver, the delegations were unable to agree on a common nomenclature again; see the communique in II ZEITSCHRIFT FÜR LUFTRECHT UND WELTRAUMRECHTSFRAGEN 3 Ig (I962).

${ }^{83}$ Article XXVII of the I955 Hague Protocol, which refers to the French text in case of inconsistency, was indeed incorporated in the United Kingdom Carriage by Air Act (196r), 9 \& 1o Eliz. 2, c.27, $\$ \mathrm{I}(2)$; see also article XVIII of the $196 \mathrm{I}$ Guadalajara Convention.

${ }^{3}$ Chauveau, supra note 37 , at 575 . The only exception to the rule lex posterior derogat legi priori was article 28 of the French Constitution of 1946, which gave superiority to treaty law over subsequent legislation; see Gallais v. Aéro-maritime Co., supra note 62 , at 186 . This unique provision was abandoned, however, in the new French Constitution of 1958; see HenRI Batipfol, Traite Elfmentrune DE DROIT INTERNATIONAL PRIVE 43 (3d ed. 1959). The seemingly similar article 66 of the Netherlands Constitution of 1956 has been restricted to 'self-executing' treaties; Erades, 6 Nedersands TijDschurT VOOR INTERNATIONAAI REChT 408 (1959).

${ }^{85}$ Such as the comments on the Warsaw Convention by U.S. Secretary of State Cordell Hull, S. Exec. Doc. C, 73d Cong., 2d Sess. 3 (1934), r934 U.S. Av. R. 240; by the German Ministry of Justice, [I933] AMTLIChE SONDERVERöFFENTLIChUNGEN DER DEUTSChEN JUSTIz No. I; by the Swiss Federal Council, [1952] III Bundesblatt 235; and by the Austrian government, Beilagen zu den stenographischen Protokollen des Nationalrates No. 432, IX, G.P. (I96I); all of which have occasionally been referred to by courts interpreting the convention.

${ }^{88} \mathrm{Kahn}$, Gesetzeskollisionen, 30 Ihering Jahrbücher I (I89I), reprinted in Franz Kahn, AbHandLUNGEN zUM INTERNatToNalen PRIVATREChT 92 (Munich 1928); see Alexander Makarov's comment in I Voprosy vozDUSHNogo prava 139 (1927), transl.: Makarov, Die zwischenprivatrechtlichen Normen des Liftrechts, I ZEITSCHRIFT FÜR DAS GESAMTE LUFTRECHT I80, I86 (I927).

${ }^{87}$ Mankiewicz, Die Anwendung des Warschatter Abkommens: Ein Beitrag atr Problematik rechtsvereinheitlichender Abkommen, 27 RABess Z. 456 (1962), and Peter H. Sand, Choice of Law in Contracts of International Carriage by Air, p. 39 (thesis, McGill, 1962).

${ }^{83} \mathrm{Kaftal}$, Quelques reflexions au sujet d'une convention internationale concernant le transport par aéronefs des personnes, des bagages et des marchandises, ir REvuE JURIDIQUE INTERNATIONALE DE LA 
a common authority for the interpretation of uniform air law conventions, the courts of different member states will interpret the conventions in different ways "so that the apparent unity of the law falls to pieces."89 Several proposals for the establishment of an international supreme court for uniform air law failed, ${ }^{00}$ partly because they were considered as incompatible with North American federal structures. $^{91}$ Pious resolutions for the "promotion of uniform interpretation of the international private air law conventions" were equally unsuccessful. ${ }^{92}$

Nor are there any precise canons of interpretation for the conventions. General principles such as the Granada resolutions of the Institute of International Law ${ }^{\mathbf{9 3}}$ are of little avail. Historical interpretation by reference to travaux préparatoires is inadmissible in some legal systems, ${ }^{94}$ is likely to be rejected by states who did not themselves participate in the drafting work, ${ }^{95}$ and after thirty years of progress in aviation may be either irrelevant-as the "air charter" dispute shows ${ }^{96}$-or plain

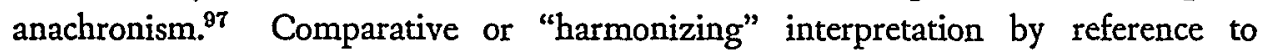
foreign case law ${ }^{98}$ inevitably seems to favor the strongest party, namely, the air carrier. In the absence of a reliable international law reporter for uniform air law cases, ${ }^{09}$ selected foreign precedents are sometimes presented to the courts by airline

LOCOMOTION ÁRIENNE 129, 135 (1927); and Schreiber, Der Entwurf eines internationalen Abkommens über die Haftung des Unternehmers bei internationalen Lufttransporten, I ZEITsCHRIFT FÜ̈ DAS GESAMTE LUFTRECHT 22, 25 (I927).

${ }^{80}$ Martin Wolfp, Private International Law 51 (2d ed. 1950).

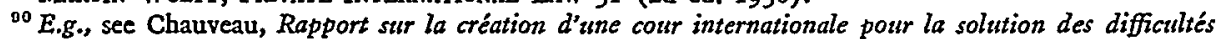
nées de l'interprétation et de l'application des conventions internationales en matière de droit aérien, 9 REVue FRANÇAISE DE DROIT AERIEN 465 (1955).

${ }^{01}$ See the comments by A. B. Rosevear, in RePort on THE 48Th CONFERENCE of the INTERNationaL LAw Association 33I (1958), and Rinck, Ein internationaler Gerichtshof fïr Angelegenheiten des Luftprivatrechts?, 7 ZerrschruFT FüR LUFTRECHT 33 (1958).

${ }^{02}$ See recommendation E of the I955 Hague Conference, Final Act, ICAO-Doc. 7686 II.3I, following several proposals since 1950; of. Drion, Towards a Uniform Interpretation of the Private Air-Law Conventions, I9 J. AIR L. \& Con. 423 (I952).

${ }^{93}$ Resolution on the Interpretation of Treaties, adopted at Granada on April 19, 1956; 46 ANNUAIRE de I'INSTITUT DE Droit INTERnational 364 (1956).

ot On "the English-speaking judges" see GuTrermge, op. cit. supra note 36, at II6; but cf. McNair, L'application et l'interprétation des traités d'après la jurisprudence britannique, 43 REcuEIL DES Cours de l'Académie de Droit International 25x, 267 (r933), and Radin, A Short Way with Statutes, 56 Hanv. L. Rev. 388, 395 (1942). Preparatory work of the Warsaw Convention has been cited in at least four American cases interpreting the treaty; Sand, supra note 87 , at 34 .

${ }^{\circ}$ Soubeyrol, The International Interpretation of Treaties and the Consideration of the Intention of the Parties, 85 Clunet 687, 715 (I958). Several states which ratified the $x 955$ Hague Protocol (e.g., the Soviet Union) were not members of the drafting ICAO Legal Committee.

${ }^{06}$ See Kurt Grönfors, Atr Charter and the Warsaw Convention it (I956), and Jacob W. F. Sunderg, Air Charter: A Study in Legal Development 200 (ig6r).

${ }^{07}$ See the comments by Michel de Juglart on Stichting Rotterdamsche Diergaarde v. Air France, Arrondissementsrechtsbank Amsterdam (June 15, I956), in I2 REVUE TRIMESTRIELLE DE DROIT COMMERCIAL 216-217 (1959).

${ }^{88}$ GUTTERIDGE, op. cit. supra note 36 , at $\mathrm{III}$; Bayer, Auslegung and Ergänzung international vereinheitlichter Normen durch staatliche Gerichte, 20 RABELs Z. 603 (I955); and Kisch, Statutory Construction in a New Key: "Harmonizing Interpretation," in 20th Century Comparative and Conflicts Law: Legal. Essays in Honor of Hessel E. YNTEMa 262 (196I).

${ }^{\circ}$ The cxisting compilations are either incomplete (note $\mathrm{r}_{77}$ infra) or highly "selective," such as the Air Carriers' Liability Reports (formerly IATA Law Reporter, Gazdik ed.) circulated by IATA to its member airlines. 
attorneys, with the candid request "not to place the national air transport industry at a competitive disadvantage with respect to foreign air carriers."100 Functional or teleological interpretation by reference to the objectives of unification have led different national courts to suprising contradictions over the "primary purposes" of uniform air law conventions. ${ }^{101}$ To make things worse, in the famous Froman case the majority opinion of Judge Desmond found support in "the general purport and purpose of the [Warsaw] Convention,"102 while the dissenting opinion by Judge Conway reached the opposite conclusion invoking "the aims and intendments" of the same text. ${ }^{103}$

In actual practice, the courts of the various states "will be prone to construe an ambiguous term in the sense in which it is understood by their own law."104 It is a traditional habit for judges interpreting uniform law first to pay lip-service to international unification, ${ }^{105}$ and then to conclude, as in Bochory v. Pan American Airways: "[T] $[$ his question is one of interpretation of the Warsaw Convention, and it is the law of this jurisdiction which determines the interpretation." 100 Whether this attitude should be attributed to the "lack of interest of many judges and practising lawyers as regards anything foreign to their own legal system, often combined with a comfortable superiority complex"107 or to straight chauvinism, ${ }^{108}$ is a moot point. The fact is that, because of elementary differences of legal concepts and methods of statutory interpretation, the general trend is not towards greater uniformity and harmony of decisions, as is sometimes believed, ${ }^{102}$ but rather, as René $\mathrm{H}$. Mankiewicz points out, towards "judicial disunification" of private air law. ${ }^{110}$

${ }^{100}$ Compare the argument for defendant in Vizioz v. Air France, 8 REVUE FRANĢAISE de Drotr AÉrien 421 (1954), and Chauveau's comments on Hennessy v. Air France, $i d$. at 69.

${ }^{103}$ Compare Noel v. Iinea Aeropostal Venezolana, supra note 78; Berner v. United Airlines Ine., I49 N.Y.S.2d 335 (Sup. Ct. 1956), I956 U.S. \& Can. Av. R. I34; and Froidevaux v. SABENA, Obergericht Zürich (January 23, I938), [1958] Bulletin de L'Association Suisse de Droit Afrien (No. 3) 4 .

${ }^{102}$ Froman (Ross) v. Pan American Airways Inc., 299 N.Y. 88, 85 N.E.2d 880 (1949), 1949 U.S. Av. R. 168,175 . ${ }^{108}$ Id. at 189 .

${ }^{104}$ WOLFr, op. cit. supra note 89, at 5x; accord: Mann, The Interpretation of Uniform Statutes, 62 L.Q. REv. 278 (1946), and BATIFFOL, op. cit. supra note 84, at $4 \mathrm{~T}$.

${ }^{108}$ E.g., Flying Tiger Line v. United States, I70 F. Supp. 422 (Ct. Cl. 1959), 1959 U.S. \& Can. Av. R. II2, II7: "The document being a writing accomplished by international agreement, an American court does not have the right to interpret it as freely as it might interpret an American statute ar contract."

${ }^{106}$ Bochory v. Pan American Airways Inc. (N.Y. Sup. Ct., April 23, I956), I956 U.S. \& Can. Av. 209.

${ }^{107}$ Drion, supra note 92, at 424 .

${ }^{208}$ Chauveau, as quoted by Fautz in Emery v. SABENA, I4 REVOE FRANÇISE DE DROIT AERIEN 42I, 423 (1960); cf. Ariëns, "Chauvinisme judiciaire," 9 Nederlands Tijoschrift voor Internationari RECHT I (I962).

${ }^{109}$ Bayer, supra note 98, at 609 n.29; Giuseppe Guerrert, American JuRJsprudence on thr Warsaw Convention 4 (1960); and Marcel le Gofp, Manuel de droit aErien: Droit prive 154 (196r).

${ }_{120}$ Mankiewicz, Le sort de la Convention de Varsovie en droit écrit et en Common Lalv, in 2 MÉlanges en L'HONNeUR de PAUL Roubier 105, iog (I961), and supra note 87, at 459. 


\section{Amendments}

It is essentially due to these "centrifugal tendencies in air law," as Bin Cheng has called them, ${ }^{111}$ that periodic amendments of the original conventions become necessary. The Warsaw Convention of I929 had hardly entered into effect when the first proposals for revision were put forward, were discussed in various international committees, and eventually resulted in the r955 Hague amendments and the I96r Guadalajara supplements.

A famous example is the oft-maligned definition of faute lourde équivalente au dol (article 25 of the Warsaw Convention), known as "the result and the starting point of a comedy of errors."112 After experimenting with two other formulations in the Rome Conventions of I933 (article I4) and I952 (article I2 \$ I), the international lawmakers finally agreed on a paraphrase of contemporary judicial definitions of "wilful misconduct" in the 1955 Hague Protocol. ${ }^{113}$ Similar developments caused changes in article 9 (documentary requirements) and article 22 (limits of liability), after United States court decisions had openly revolted against the clear text of the old convention. ${ }^{114}$

The late Annold W. Knauth once characterized this as "a race between the makers of uniform laws and the haphazard work of legislatures and judges in the $25^{\circ}$ or more states of this modern world."115 Unfortunately, as compared with national law-makers, the framers of international uniform law are severely handicapped in this race:

(a) Unlike revised statutes, amendments of international conventions do not automatically supersede the original text. Each state is free to stick to the unamended original treaty or to adopt the revised edition of its choice. As the provisions relating to the coexistence of different subsequent editions of uniform air law are most unsatisfactory, ${ }^{116}$ there emerges a new type of conflicts in private international law: the conflict of conventions. ${ }^{117}$

(b) To amend an international air law convention is far more complicated than to amend national law. By the time the amendment has been drafted in inter-

${ }^{121}$ Bin Cheng, Centrifual Tendencies in Air Law, to CuRrent Legal Prob. 200 (1957).

${ }^{123}$ Huibert Dron, Limitation of Liabimities in International Air Law i7o (1954).

${ }_{113}$ Particularly the instruction to the jury by Barry, J., in Horabin v. BOAC, [1952] 2 All E.R. IoI6 (Q.B.).

${ }^{114}$ See American Smelting \& Refining Co. v. Philippine Airlines Inc. (N.Y. Sup. Ct., June 2I, I954), 1954 U.S. \& Can. Av. R. 22I; and the jury verdict in Goepp v. American Overseas Airlines Inc. (N.Y. Sup. Ct., Oct. 25, x95I), I95I U.S. Av. 527 (later modified on appeal, see Bin Cheng, stupra note III, at 225).

115 Knauth, Aviation Law and Maritime Law, 35 Chicago Bar Record I99 (I954).

116 Article XVIII of the Hague Protocol; see ICAO-Doc. 7686 I.290-292, and Verplaetse, Sources of Private International Air Law, 7 INT'L \& CoMP. L.Q. 405, 4II (1958).

117 Garnault, Le Protocole de la Haye, to Revue pRANÇAISE DE DROIT AERIEN 6, 9 (r956); Mankiewicz, Confits entre la Convention de Varsovie et le Protocole de la Haye, I9 Revue générale de l'air 239 (1956); de La Pradelle, comments on Maché v. Air France, 24 Revue Gínterale de L'aIr 298 (I96r); and Gazdik, The Conflicts and State Obligations Under the Warsaw Convention, the Hague Protocol and the Guadalajara Convention, 28 J. Arr. L. \& CoM. 373 (1961-62). 
national committees, adopted by a diplomatic conference, and ratified by the required number of states, it is usually ripe for amendment itself.

\section{B. Substantive Problems}

Harold Caplan, pointing to unratified air law conventions, asks: "Was this because they were imperfect? Or was it because they no longer satisfied the needs which were felt to be urgent long before they were signed? If the answer to either of these questions were yes-then this might be more of an indication of intrinsic defects in the Conventions, rather than an indication of the slothful nature of governments."'118

\section{Consensus}

During the early period of air law unification, it was relatively easy to obtain government approval for international uniform law-for the simple reason that there was little or no national legislation on the new subject of aviation. The CITEJA conventions often preceded the work of national legislators, who willingly seized on international models for their statutes. ${ }^{119}$ The situation changed, however, as aviation became a routine field of legislation. Air law lost its novel character and was integrated in the respective legal systems. States accumulated their own legislative and jurisprudential experience with aviation matters, and now seem increasingly reluctant to abandon national patterns, or to accept "alien" concepts. ${ }^{120}$

As a result, the drafting of air law conventions more and more involves considerations of national prestige and diplomatic compromise rather than of optimal solutions. The very philosophy of "creative codification" is changing into a "restatement philosophy" based on preferred patterns of positive law.

It is no secret that this affects the quality of uniform law, too. As Kurt Grönfors puts it, "a good rule with world-wide acceptance is better than a better rule opposed by a number of states. One has to pay a price for international uniformity."121 The trouble is that the present international institutions-based on the classical one-state-one-vote system-afford no adequate remedy. Drafting sessions may be dominated by representatives of states more politically ambitious than interested in a workable unification $;^{122}$ and apparent majority decisions at ICAO meetings or at diplomatic conferences often overrule dissenting "minorities" representing the bulk of world air transport. A striking example is the I952 Rome

${ }^{118}$ Caplan, The Law versus Science in Aeronautics, 65 J. Royal Aeronatutical Soc'r 45I, 474 (I96r).

${ }_{110}$ This is still true for a number of "new states"; but see note 163 infra.

${ }^{120}$ For a waraing against foreign air law concepts which might remain "anomalies" or "Cinderellas" in the national environment of the law, see Schweickhardt, Der Einfluss des internationalen Luftrechts auf die Privatrechtsentwicklung, in JouRnÉ D'ÉTUDE DE DROIT AERIEN 9, Ig (I96r).

${ }^{121}$ Grönfors, Why Not Independent Contractors? [1964] J. Bus. I. 25, 27; cf. Wetter, Possible Simplification of the Warsaw Convention Liability Rules, 15 J. A1r L. \& Com. I, 3 [1948], postulating that the text be "universally acceptable to the various states."

${ }^{122}$ Brown, loc. cit. supra note 79. 
Convention, which is considered as unacceptable by the United States ${ }^{123}$ and by many European states (both West and East). ${ }^{124}$ Instead, it was ratified by a number of states unlikely ever to see any major air traffic among each other.

\section{Economic Factors}

Carl Wieland once said that the international unification of all private law is "but a dream, and not even a nice one,"125 a view shared by Roscoe Pound. ${ }^{126}$ In addition to the natural diversity of legal systems in the world, differences in national and regional economic standards can prevent an all-out unification.

To mention just one example: Several air law conventions contain monetary limits of liability for accident damages. The I929 Warsaw Convention, as well as the I933 and 1952 Rome Conventions and the I955 Hague Protocol, expressed these uniform ceilings in a special gold standard based on the r928 French gold currency (the "Poincaré-Franc"), ${ }^{127}$ thus creating an international monetary system of their own. ${ }^{128}$ The advantage of the gold standard was then-and still is-seen in the fact that it is almost perfectly "static," i.e., immune against variations of currency exchange rates, national income, and so on, and therefore keeps the limits equal and stable (a) internationally, and (b) intertemporally. ${ }^{129}$ This, of course, greatly facilitates the calculation of risks and insurance in international aviation, and considerably reduces the carriers' costs.

In practice, however, the measure of personal damages for wrongful death and injury is directly proportionate to income. For instance, in Tuller $v_{.} K L M_{\text {, }}^{130}$ the court calculated the compensation for the deceased air passenger's dependents by the rule-of-thumb of $D=\frac{I \times L}{2}$ (multiplying Tuller's annual income $I$ by his

${ }^{293}$ See the official commentary in 28 Dep'r State Buld. 221 (1953).

124 See Rinck, Damage Cansed by Foreign Aircraft to Third Parties, 28 J. Arr L. \& CoM. 405 $(x 961-62)$.

${ }^{225}$ As quoted by Riese, Réflexions sur l'unification internationale du droit aćrien, sa situation actuelle, ses perspectives, 5 REvue FRANĢAISE DE DROIT AERIEN I3I, I47 (195I).

${ }_{120}$ Pound, The Idea of a Universal Law, I U.C.L.A. L. REv. 7 (I953).

${ }^{197}$ On Raymond Poincaré's currency of June 25, 1928, (65 $\frac{1}{2}$ milligrams gold of millesimal fineness 900 per unit) see John MAYNard Keynes, The Stabilization of the Frane, in Essays in Persuasion ri3 (I93I, rev. ed. 1952). France later abandoned her gold currency, so that the "valeur d"or" today has to be calculated by U.S. dollars in most countries-including France: see the parliamentary reply from thẹ Minister of Economics and Finance, [1949] Journal Officiel, Déb. Cons. Rép. 2418; 38 Rev. Cr. DR. INT'L PR. 730 (r949).

${ }^{128}$ Fritz Alexander Mann, The Legal. Aspects of Money 446 (2d ed. I953). Sec, however, article $22(4)$ of the Warsaw Convention, which permits statutory conversion of the gold sum into national currencies "in round figures"; ARTHUR NUSSBAUM, MONEY IN THE LAW 443 n.43 (I950). As a result, the official limit of liability in Belgium was fixed ne varietur at 250,000 Belgian Francs per passenger (article 3 of the statute of April 7, r936), while the present-day equivalent of the Warsaw gold sum is approximately twice that amount; Verplaetse, Das Luftrecht in Belgien, I2 ZerrschrifT FÜR LUFTREChT UND WELTRAUMREChTSFRAGEN 35, 39 (Ig63).

${ }^{120}$ See, in general, John Maynard Keynes, A Treatise on Money (I930).

${ }^{130}$ Tuller v. KLM, 292 F.2d 775 (D.C. Cir. I96I); see Wolcott, Some Aspects of the Trial of a Warsaw Air Crash Case, 67 Case \& Com. (No. 5) 8 (I962). For a more sophisticated calculation of damages on the basis of income, see Leroy v. SABENA (S.D.N.Y., March 17,1964 ), 8 Av. Cas. I8, $143(1964)$. 
years of life expectancy $L$, and dividing by 2). For actuarial purposes, average personal damages $D$ may be treated as a mathematical function of average personal income: $D=f(I)$, even if average life expectancy is assumed to be unrelated to income. $^{13 I}$ Consequently, the measure of personal damages is bound to vary: (a) internationally, depending on the average national income per capita; (b) intertemporally, following the income index, which due to increasing productivity and technical progress is constantly on the rise. In other words, if standards of living are "dynamic" variables, so are the standards of dying in air accidents.

Estimating the index of average income per capita in three sample member states of the Warsaw Convention (United States: France: India) at 40, 20, and $x$, respectively, we obtain the following

\section{- Average Measure of Personal Damages in Air Accidents ${ }^{192}$}

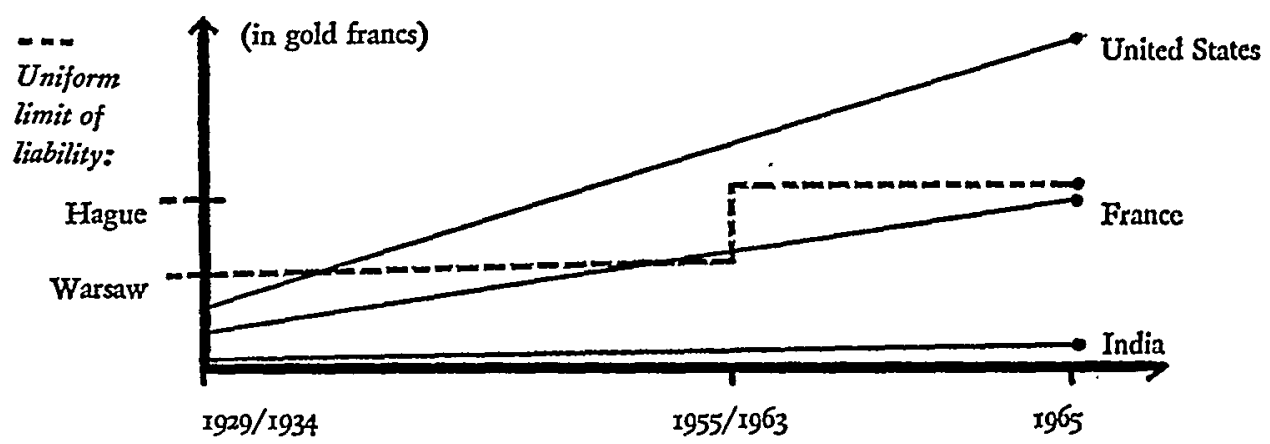

The 1929 Warsaw Convention limited the carrier's liability for personal damages to 125,000 gold francs per passenger, i.e., approximately $\$ 8,300$ today. It appears that this amount was adequate to the American measure of damages when the United States joined the Convention in 1934, a few months after President Roosevelt's dollar devaluation. ${ }^{183}$ During the post-war years, however, the measure of damages - geared to climbing personal incomes mainly by the contingent-fee system ${ }^{184}$ rapidly overtook the Warsaw standard. At the r955 Hague Conference the U.S. delegation proposed to triple the uniform gold sums; against heavy opposition from low-income countries, the amount was merely doubled to 250,000 gold francs

${ }^{131}$ However, countries with high per capita income also have higher average life expectancy: Dunsdorfs, Average Expectation of Life as an Index of Civilization, 74 (I) Weltwirtschnftricues ARchiv 267 (1955).

${ }^{282}$ The graph is a gross oversimplification, since no accurate comparative statistics are available. Apart from the excellent 1941 Sweeney Report to the Civil Aeronautics Board, some recent figures on air accident compensation are compiled in StafF of INteragency Group on International Aviation, Thr Warsaw Convention and the Hague Protocol (Federal Aviation Agency IGIA-Doc. 23/1.1o A, 1962), Annex A, Tab. r.

${ }^{133}$ The Gold Reserve Act of January 3, r934, 48 Stat. 337, c.6, Jan. 30, r934, had just raised the equivalent of 125,000 gold francs from $\$ 4,898$ to $\$ 8,292$; $c$. Report of Air Coordinating Committec, Economic Division, ACC-Doc. 5r/22. I4 A, as quoted by Orr, The Rio Revision of the Warsaw Convention, 2 I J. AIr L. \& CoM. 39, 48 (I954).

${ }^{184}$ See Franklin, Chanin \& Mark, Accidents, Money and the Law, 6I Colom. L. REv. I (196r). 
(approximately $\$ 17,000$ ) per capita. ${ }^{\mathbf{1 3 5}}$ Now that the new limit has come into effect (on August r, 1963), West European states begin to realize that this is no longer sufficient to meet their own rising standards of income and personal damages, ${ }^{136}$ and in the United States even the $\$ 25,000$ limit offered at The Hague is considered too low. ${ }^{137}$

Recent suggestions to raise the uniform limits once more are missing the point. The "income gap" between the "founding members" of the Warsaw Convention and the developing countries (which now supply almost two thirds of the membership) is constantly widening. ${ }^{138}$ If a uniform medium limit is fixed by majority decision, high-income states will be forced either to withdraw altogether ${ }^{139}$ or to create supplementary national schemes whereby the beneficiaries of the uniform limit (i.e., the airlines, to whom it is an indirect subsidy) compensate the victims. ${ }^{140}$ The "static" uniform standard thus either eliminates important member states, or necessitates adjustments to "dynamic" national standards and defeats itself in the process. The measure of personal damages, for one, is a perfect illustration of what Drion calls the borderland of feasible international unification. ${ }^{141}$

\section{Parkinson's Air Law}

A basic policy rule for the elaboration of uniform air law, as formulated by Maurice Lemoine, is "not to accept any other source of inspiration than the needs of practice."142 Unfortunately, the very creation of permanent organizations and committees somehow appears to undermine such self-restraint.

According to Cyril Northcote Parkinson's fundamental laws of administration, ${ }^{143}$ any organization or committee suffers from an inherent urge to justify its existence by constant activity (regardless of the results). CITEJA and the Legal Committee of ICAO are no exceptions from the rule. Once the production of uniform air law

${ }^{2 a s}$ See Calkins, Hiking the Limits of Liability at The Hague, AM. Soc'y INT'L LAw, ProceEdINGS OF THE 56Th ANNUAL MeEting $\times 20$ (I962).

${ }^{186}$ See Lord Denning's remarks during the debates on ratification of the Hague Protocol, $23 I$ H.L. DEB. 924 (196r).

${ }^{187}$ Metzger, Limitation of Liability for Aircraft Accidents in International Transportation: The Warsaw Convention and the Hague Protocol, Am. Soc'y Int'L LAw, Procendngs of the 56th Annual MeETiNa 128, 130 (I962).

${ }^{183}$ See GunNar Mrrdal, Economic Theory and Under-developed Regions (I957).

${ }^{180}$ Lissitzyn, The Warsaw Convention Today, AM. Soc'y INT'L LAw, Proceedings of the 56TH Annual Meeting 115 (1962); Wright, Warsaw Convention's Damages Limitations, 6 Clev.-Mar. L. REv. 290 (I957).

${ }^{160}$ See bill, S. 3II9, 88th Cong., 2d Sess. (I964); Sand, Limitation of Liability and Passengers' Accident Compensation Under the Warsaw Convention, II AM. J. Comp. L. 2 I (1962).

${ }_{161}$ DrioN, op. cit. supra note II2, at 42: "If there is any field in which unification of the law on a world-wide basis would be inappropriate, it is the field of the amount of damages to be paid in case of death or injuries. For in few areas local views and circumstances of a social and economic character are of such importance." Even on a national level, uniform personal damages are a mixed blessing: Selmer, Limitation of Damages According to the Circumstances of the "Average Citizen," 5 Scandinavian Studies IN LAW I33 (I96r).

${ }^{142}$ Lemoine, Essai sur les perspectives d'avenir du droit aérien international, 2 REvUE FRANçISE DE DROIT AÉRIEN I33 (I948).

${ }^{148}$ Crril Northcote Parkinson, Parkinson's Laft (1957). 
was institutionalized, the supply became increasingly independent of demand. With due respect to their positive achievements, the two committees can safely be said to have produced a fair amount of "uniform law" that was either premature, superfluous, or at best experimental. Their most notorious miscarriage was the law on third-party damage by aircraft: After CITEJA's 1933 Rome Convention and the I938 Brussels Protocol turned out to be failures (having received 5 and 2 ratifications, respectively), ICAO launched the equally unloved 1952 Rome Convention, ${ }^{144}$ and presently thinks of suprising its members with a new model.

One might argue that zeal is an inevitable operational defect, and that unratified conventions can do no harm. This is not so. Quite apart from the considerable waste of time and money by international committee meetings and diplomatic conferences, each unnecessary or unacceptable convention destroys some good-will and "throws discredit on the entire work of international unification of air law."145 The problem is substantive, and may have its repercussions on the policy of states regarding uniform law as a whole.

\section{III}

\section{Future Prospects of Unification}

It is submitted that what uniform air law needs is not further expansion, but more reflection and some overhaul. Our analysis would seem to indicate that the present "crisis of growth" has more operational than substantive causes. Something will have to be done about this, lest defective bits and pieces, the by-products of much hit-and-run unification, grow into major problems.

\section{A. Alternatives}

Because of the general international enthusiasm for the method of uniform legislation in air law, alternative ways of dealing with the ills of conflicting national law may have been neglected.

First, the hidden virtues of the stepchild of private international air law, the "clinical" rules of conflict of laws, seem to have been underestimated in the past. ${ }^{140}$ Almost thirty years ago, R. Coquoz wrote: ${ }^{147}$

\footnotetext{
144 Supra notes $79,123,124$.

${ }^{145}$ Schaerer, supra note 46 , at 40 . E.g., Canada, which was one of the first states to ratify the 1952 Rome Convention, (see Foreign Aircraft Third Party Damage Act, [1955] Stat. c.15) now regrets the ratification: Thorne, Anticipated Problems in Interpretation and Application of "Foreign Aircraft Third Party Damage Act," [I960] Papers Can. B. Ass'w III.

${ }_{106}$ This was largely the fault of European jurists who considered uniform choice-of-law rules as inferior to unification, and as "more satisfactory to the lawyers than to the interested parties": Ripert, L'unification du droit aérien, I REVUE GENERALE DE DROIT AERIEN 25I, 258 (I932); cf. the minutes of the Warsaw Conference, II CONFERENCE INTERNaTIONALE DE DROIT PRTVE AERIEN, 4-12 OCTOBRz I929 VARSOVIE (1930), ICAO-Doc. 7838, at 44; English translation in Calkins, The Catuse of Action Under the Warsaw Convention, 26 J. AIR L. \& CoM. 217, 233 (1959).

${ }^{147}$ Coquoz, Les perspectives d'avenir du Droit Privé International Aérien, 7 REvuE otenéule dE DRoIT AÉRIEN 29, 3 I (1938) (author's translation).
} 
Once CITEJA will have finished its work, and the international conferences will have legislated on the main problems of private air law; once we will know the success or failure of the conventions drafted, from the number of ratifications or adherences; then, the moment will have come to complete the work of unification, and to formulate the rules of Conflict of Air Laws designed to solve those questions which were not successfully settled by internationally uniform rules.

It may well be that this moment has come, judging from the renewed attention paid to conflicts of air laws, particularly by the Institute of International Law. ${ }^{148}$ It comes at the very time when American courts dealing with inter-state conflicts in aviation are beginning to throw some dogmatic anachronisms over board, ${ }^{149}$ so that-as Brainerd Currie says-"we have all been left free to work toward a better law of conflict of laws." 150

Second, the rules on jurisdiction and foreign judgments may deserve more concern. There has been a startling increase in litigation regarding the proper forum under the Warsaw Convention; ${ }^{151}$ jurisdictional provisions were decisive for the failure of the Rome Convention; ${ }^{152}$ and an exhaustive report by Michel Smirnov has brought out the deplorable state of affairs as regards execution of foreign judgments in air law. ${ }^{153}$ More policy research is needed into the "forum conveniens"154 or, as Drion puts it, the "natural forum"155 which can legitimately claim

${ }^{118}$ Resolution Concerning Conflicts of Laws in the Law of the Air, 5Ist Sess. Brussels 1963 , English translation by B. A. Wortey, 58 Ass. J. INT'L L. I20 (1964); based on the report by Makarov, Conflits de lois en matière de droit aérien, 48 ANNUAIRE DE L'INSTITUT DE DRoIT INTERNATIONAL pt. $\mathrm{I}$, 359, 405 (1959), resuming an earlier project by F. de Visscher, Les conflits de lois en matière de droit aérien, 48 Recueir des Cours de I'ÁAdEMIE dE DRort InTERnational 294 (1934); of. HermanN Múliler, Das Internationale Privatrecht der Luftfahrt (Thesis, Kiel x932); Jürgen Frese,

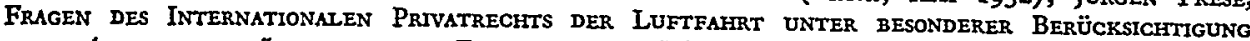
EINER ANWENDUNGSMÖ́lichKeIt des FlAGgenRechrs (Thesis, Cologne 1940); and Riese, Internationalprivatrechtliche Probleme des Luftrechts, 7 ZEITSCERIFT FÜr LUFTrECHT 272 (1958).

${ }^{149}$ Compare Kilberg v. Northeast Airlines Inc., 9 N.Y.2d 34, 172 N.E.2d 526 (1961); Pearson v. Northeast Airlines Inc., 309 F.2d 553 (2d Cir. 1962); Griffith v. United Airlines Inc. (Pa. Sup. Ct, Oct. 14, 1964), 9 Av. Cas. I7, 225 (1964); with Drion, The Lex Loci Delicti in Retreat: A Foreigner's Remarks on Babcock v. Jackson, in FESTSCHRIFT Für OTTO RIESE 225 (1964).

${ }_{151}^{150}$ Currie, Conflict, Crisis and Confusion in New York, 1963 Dure L.J. 1,55 (1963).

${ }^{161}$ E.g., Rotterdamsche Bank v. BOAC, [1953] I All E.R. 675 (Q.B.); Djabbarzade v. Linee Aeree Italiane, Obergericht Zürich (Jan. 15, 1958), [1958] BULLETIN DE L'Association Suisse DE DRort AÉRIEN (No. 2) 8; Diop v. Air France, Court of Appeal of Dakar/Senegal (March 15, 1963), I7 REvUE FRANĢAISE DE DROIT AÉRIEN 234 (1963); Pardonnet v. Flying Tiger Line Inc. (N.D. Ill., June r9, 1964), 9 Av. Cas. 17, 182 (1964), and previous American cases cited therein; of. Colclaser, Jurisdiction in Private International Air Law Cases, 49 Mich. L. Rev. II63 (I95I); Werner RoMang, Zustündigkeit UND VolistreckbarkeIt IM INTERNATIONALEN UND Schweizerischen LuFTPRivatrecht (thesis, Zürich 1958); Grandbois de Villeneuve, Compétence jurridictionnelle et lex fori dans la Convention de Varsovie, 8 McGmL L.J. 284 (1962); McKenry, Judicial Jurisdiction under the Warsaiv Convention, 29 J. ArR L. \& CoM. 205 (1963); and Robbins, Jurrisdiction under Article 28 of the Warsaw Convention, 9 McGinI L.J. 352 (1963).

${ }_{262}$ See Brown, supra note 79, and Anton Toepper, The Single Forum Method and the Unification of International Private Air Law (thesis, McGill University 1955).

${ }^{16 a}$ International Chamber of Commerce, Execution of judgments of Foreign Courts in Connection with Air Law, 27 J. Air L. \& CoM. 180 (1960); cf. Garnault, L'exécution des jugements à l'étranger en droit aérien, REPORT ON THE 46TH CONFERENCE OF THE INTERNATIONAL LAw Association 302 (I954).

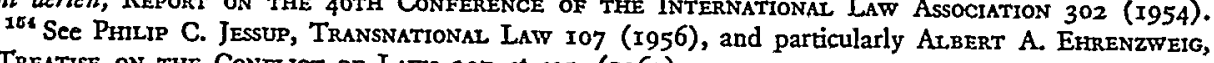
A Treatise on the Conflict of Laws 307 et seq. (1962).

${ }_{105}$ Drion, De ratio voor toepassing van yreemd recht in zake de onrechtmatige daad in het buitenland, (1949) Rechtsgeleerd Magazijn Themis 3, 49, 62. 
recognition abroad. In the light of the recent success of arbitration in public international air law, ${ }^{156}$ there may also be some reason to reconsider the positive advantages of commercial arbitration clauses in private air law conventions. ${ }^{167}$

Thirdly, a reappraisal of various methods to avoid conflicts of laws by "private" means is long overdue. This requires some "fact research in law."168 Standard conditions of carriage, court-approved or not, are facts of international air transport profoundly affecting the law of carrier-passenger relations (documents of carriage), and of carrier-carrier or carrier-middleman relations (charter and interchange of aircraft). "Private" accident insurance by airlines can modify the entire system of liability to passengers under the Warsaw Convention; ${ }^{\mathbf{1 6 9}}$ hull insurance contracts and equipment trusts can be used to circumvent the system of aircraft finance contemplated by the Geneva Convention. ${ }^{160}$ It would seem logical, therefore, first to delimit the area which can, and the area which cannot, be left to "private unification." If private associations such as IATA are recognized as performing a genuine law-making rôle-as in actual practice they do-then the question arises whether their quasi-legislative procedures grant adequate representation to all groups affected (e.g., passengers; aircraft users; travel agents; air freight forwarders). If, however, such private standardization has substituted "a manifest abuse of economic power"161 for freedom of contractual bargaining, ${ }^{162}$ then this might be an urgent indication that the process of private unification of air law is in need of democratization.

\section{B. Consolidation}

The body of uniform private air law, as it now stands, is not a coherent code, but a collection of autonomous uniform statutes, divergent and sometimes contradictory in terminology, in scope of application, and in substance. 'This may not be too different from comparable situations on the level of national statutory law; but it is far more mischievous in the case of international models for world-wide legislation. The recent practical experience of ICAO legal officers who were faced

${ }^{168}$ See the U.S.-France and the U.S.-Italy arbitrations in 3 American Societ'y of INTERNational Law, International. Legal Materials 668 and Ioor (1964); cf. Larsen, Abritration in Bilateral Air Transport Agreements, 2 ARRIV FOR LUFTRETT 145 (I964).

${ }^{167}$ For carriage of goods by air, see articles $32-33$ of the Warsaw Convention. IATA favors an extension of arbitration to passenger transportation; see ICAO-Doc. 7450-LC/136 II.IIr. Among the advantages of arbitration over litigation are: expertise of arbitrators, time and cost savings, finality of sentence, and no publicity.

${ }^{158}$ Nussbaum, Fact Research in Law, 40 Colum. L. Rev. 189 (1940).

${ }^{150}$ Supra note I40; of. Warkallo \& Zylicz, Liability and Insurance in Polish Air Law, RApports polonais presentís au Ge Congris INTERnational de Droit Compart i72 (1962).

${ }^{160}$ See Humphrey \& Caplan, Aviation Full Insurance and Aircraft Financing, (1960) J. Bus. L. $5 x$; and David I. Johnston, Legal Aspects of Aircraft Finance (thesis, McGill 196r).

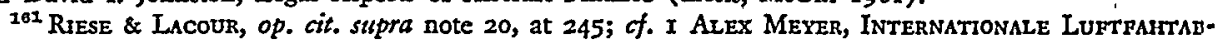
KOMMEN T59 (I953).

${ }^{182}$ See Kessler, Contracts of Adhesion: Some Thoughts About Freedom of Contract, 43 CotuM. L. Rev. 629 (I943); Wolfgang Friedmann, Law in a Changing Society 124 (x959); and Lenhoff, Contracts of Adhesion and the Freedom of Contract: $A$ Comparative Study in the Light of American and Foreign Law, 36 TuL. L. Rev. 48 (rg6r). 
with the task of drafting new aviation statutes for several developing nations as a U.N. Technical Assistance project ${ }^{163}$ strikes an alarming note in the general concert of complacency. A thorough reappraisal with a view to consolidating the conventions wherever possible would promote their universal acceptance, and facilitate future drafting. ${ }^{164}$

First, the rules of uniform law contained in air law conventions are unfit for immediate adoption as national statutes, because they are interspersed with various "general and final provisions" concerning signature, ratification, and so on, which do not concern the local legislator. ${ }^{165}$ Strict separation of these operational rules from the substantive model law, possibly by division into "treaty" and "schedule," would seem preferable for all practical purposes. Not only are the operational provisions of the conventions in need of standardization on the basis of the law of treaties as elaborated by the U.N. International Law Commission; consolidation of diplomatic practice regarding all air law conventions would also eliminate much of the political agitation that is beginning to obstruct the work of international conferences on private air law. An authoritative central registry for all treaty data would have to include not only the instruments of ratification, adherence, and reservations, but also evidence of national translations, transformations, and amendments affecting the uniformity of air law.

Second, the unification of air law must be brought in line with parallel unification movements in other fields of private law, particularly the law of international carriage by sea, rail, and road. Besides facilitating "through-carriage,"166 this might help to reduce the confusion which divergent terminology creates for everybody concerned. For instance, there are presently at least three different gold standards in existence for conventions on uniform law: a "gold franc" as used in the Berne Conventions on International Carriage by Rail ${ }^{167}$ represents a monetary value entirely different from the equivalent of the gold francs of the Warsaw and Rome Conventions on Carriage by Air, or the Brussels Conventions on Carriage by Sea. ${ }^{188}$ The interaction of private air law and maritime law has been little more than accidental, ${ }^{168}$ with the possible exception of rare national experiments like the Italian

\footnotetext{
${ }^{163}$ Reports on air legislation in new states, on file with the ICAO Technical Assistance Burcau, Montreal.

${ }^{204}$ On the paramount importance of coherent codification as a condition for the "transferability" of foreign law to a developing nation, see Takayanagi, A Century of Innovation: The Development of Japanese Law, 1868-196r, in LAW IN JAPAN 5, 37 (von Mehren ed. 1963); accord: WILHELM RöHL, FREMdE EINFLÜsSE IM MODERNEN JAPANISCHEN RECHT 3 (1959).

${ }^{100}$ Hostie, Die 'protokollarischen Klauseln' in Abkommen zur Vereinheitlichung des Privatrechts, 2

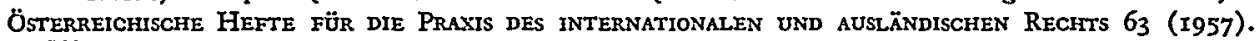
${ }^{100}$ Sec 2 RENE RODIÈre, DRoIt DES TRANSPORTS 62 (1955).

${ }^{107}$ International Conventions Concerning the Carriage of Goods by Rail (C.I.M.) and the Carriage of Passengers and Luggage by Rail (C.I.V.), of Oct. 23, I924, as amended to Oct. 25, 1952; Cam. Nos. 9064 and 9065 (I954).

${ }^{108}$ See Wick, Eisenbahnrecht tund Luftrecht, in JoURNÉES D'ÉTUdE DE DROIT AÉRIEN 2I, 28 (I96I).

${ }^{100}$ Dean Ripert happened to be among the "fathers" both of the I924 Brussels Conventions (the "Hague Rules" of maritime law) and of the 1929 Warsaw Convention; see Müller, Der Einfluss des Seerechts auf die Entwicklung des Luftrechts, in CoURs D'INTRODUCTION AU DROIT AERIEN 4I, 42 (I959).
} 
"Code of Navigation."170 The joint conferences initiated by the UNIDROITInstitute in Rome ${ }^{171}$ are a good start, but more planned coordination is required. In the global context of unification, air law is too serious to be left to the air lawyers. Rather than sending the occasional honorary observer to air law conferences, the Rome Institute should be able to provide comparative guidance based on parallel research data from all branches of international transportation law.

Thirdly, it must be realized that the conventions on uniform air law are really living organisms, subject to a natural process of evolution and differentiation depending on their environment. To steer this process, and to adapt the uniform law to changing circumstances, there ought to be a common authoritative institution. If a permanent legislative body ${ }^{172}$ or an international court of appeal is not practicable, ${ }^{173}$ new proposals for a regional court ${ }^{174}$ or for an advisory board of experts $^{\mathbf{1 7 5}}$ would deserve to be followed through. At the very least, possible "conflicts of conventions" can be anticipated and avoided by draftsmanship. ${ }^{178}$ Most urgently needed is a central recording and reporting system for all national court decisions interpreting the conventions; ${ }^{177}$ for "easy accessibility of foreign precedents may be as effective as a common court of appeal."178

\footnotetext{
Cf. Schweickhardt, Flugzeug und Schiff: Ein Vergleich ihrer rechtlichen Behandlung, [1963] Bulletis de I'association Suisse de Droit Átrien (No. 3) 1.

${ }^{170}$ Codice della Navigazione of March 30, r942; see Puinio Manca, The Italian Code of NavionTHON (1958).

${ }^{171}$ ICAO participated in the Rome meetings of organizations concerned with unification of law,
} and contributed to the "Unification of Law Yearbooks"; supra notes 32 and 36 , infra note I73. The Yearbooks and the Institute's "Uniform Law Cases" (Malintoppi ed.) contain a few cases on the Warsaw Convention (bus see note 177 infra); and $c$. ANTonio Matintoppi, Diritro uniporme a diritro INTERNAZIONALE PRIVATO IN TEMA DI TRASPORTO (I955).

${ }^{172}$ Analogous to the rôle of the ICAO Council in adopting the "Technical Annexes" (supra note 34); proposal by Saporta, L'élaboration du droit international aérien, 15 REvuE géNERALE DE L'AIR 413 (r952).

${ }_{173}$ Supra notes 90-92; see the report by the ICAO Legal Bureau, Note on the Question of the Divergencies in the Interpretation of Uniform Latv and of the Appropriate Means to Avoid Such Divergencies, [1959] Unification OF LAW YeARBOOK 315.

${ }^{124}$ In the framework of the European Community, as suggested by Riese, Une juridiction supra. nationale pour l'interprétation du droit unifié, I3 REVUE INTERNATIONALE DE DROIT COMPARE 717, 735 (196I); cf. Riese, Einheitliche Gerichtsbarkeit für vereinheitlichtes Recht?, 26 RAnELs Z. 604 (196r).

${ }^{175}$ Margalioth, $A$ Unified System for the Interpretation of Private Air Law Conventions, 3 It Dinmro AEREO 221 (I964).

${ }_{170}$ Supre notes 116 , II7. Repeated warnings by the Dutch delegation were neglected at the Hague and Guadalajara conferences; see also ICAO-Doc. 8I37-LC/ I47 I. ז25-ז27 (1960).

${ }_{177}$ There are now approximately 200 reported cases on the Warsaw Convention alone, rendered in some 25 member states including such far-liung jurisdictions as the Malayan Court of Appeals, the People's Civil Court of Prague, and the International Tribunal of Tangier. Except for a unique attempt by ICAO (Doc. No. 36 of the Hague Conference, Cases on the Warsaw Convention r929" I955 (Mankiewicz ed. 1955), of. E. Martinez Martinez, Jurisprudencia internacional sobre la conVENCtón DE VARSOVIA DE 1929 (Santiago de Chile 1962), they have never been systematically compiled. The IATA "Air Carriers' Liability Reports" (supra note 99) and the UNidrorr "Uniform Law Cases" (supra note I7I) are useful, but far from complete; the remainder is scattered in two overlapping national reports (U.S. \& Can. Av., and $\mathrm{CCH}$ Av. Cas.), nine current foreign air law periodicals with their respective discontinued predecessors, and various other sources, some of which are occasionally abstracted in a "Card Index of International Air Law Cases" (Guldimann ed., Cologne).

${ }^{178}$ Giles, Book Review, 28 Solicitor $152 \mathrm{col}$. I (196r). 


\section{The Rôle of Scholarship}

The unification movement in air law, after having been started by a cosmopolitan group of academic lawyers, was gradually taken over by administrators, national and international. It would certainly be a mistake to link the present "crisis of growth" to this change of hands. Yet we submit that, if the crisis is to be overcome, uniform air law needs scientific attention from outside, from scholars unburdened by professional routine.

First, the methods of uniform air law must be adapted to the conditions of a time when most states have developed comprehensive national systems and concepts of air law. The elaboration of conventions no longer operates in a legal vacuum as in the pioneer days of international aviation. One has to take into account the entire body of positive air law as it exists in the more than 100 member states of ICAO, as well as in a few important non-member states. The ICAO technique of "your-law questionnaires" to all governments participating in the drafting of a new convention $^{179}$ provides a useful "supply of solutions,"180 but this is not enough. Each new drafting project ought to be preceded by a comprehensive comparative study based on national reports, ${ }^{181}$ and accompanied by an analysis of possible economic, technical, and social consequences or requirements. If the research and documentation tasks involved are beyond the resources of ICAO, they might be handled by way of "research contracting" with specialized institutions and individual scholars. ${ }^{182}$

Second, the world-wide teaching of uniform air law must be promoted and coordinated as part of the long-range planning for international unification. The conventions drafted by pioneer "law-founding generations" depend on future "lawkeeping generations" for acceptance, preservation, and development. Lawyers must be trained to make use of uniform rules that may be unfamiliar and different from national law. Just as national law schools guarantee the unity of a legal system, international uniform law needs similar institutions on a new level. ${ }^{183}$ A I956 ICAO resolution recognizes the importance of specialized legal training in this field, ${ }^{184}$

\footnotetext{
${ }^{170}$ See Guldimann, La méthode de travail das Comité juridique de l'O.A.C.I., 14 Revue françaISE DE DROIT AÉRIEN I (1960).

${ }^{180}$ The term is by Zitelmann, as quoted in Rabel, Aufgabe und Notwendigkeit der Rechtsvergleichung, 13 Rheinische Zeitscrift für ZiviL- uNd Prozessrecht des IN- UND AUsLandes 279, 287 (I925).

181 Similar to procedures used by the UNIDROIT-Institute in Rome, by the International Academy of Comparative Law, and projected for the "International Encyclopedia of Comparative Law" by UNESCO's International Association of Juridical Science.

${ }^{182}$ There are Air Law Institutes at universities in Aix-en-Provence, Buenos Aires, Canberra, Cologne, Iondon, Madrid, Montreal, Oslo, Rome, Tokyo, Utrecht, and Warsaw, which could be used in the way in which Ernst Rabel and the Max-Planck-Institute contributed to the UNIDROIT draft for the uniform law on sale of goods.

${ }^{183}$ See our forthcoming study L'enseignement post-universitaire du Droit aerospatial, I9 REvuE Française de Droit AErien (1965).

184 Assembly Resolution A.I0-40, adopted at Caracas on July I6, I956; ICAO-Doc. 7707, A.I0-P/I6 (1956).
} 
which is already available in many parts of the world. ${ }^{185}$ Yet, if such training is to further uniformity, it must follow common guidelines. Hence the need to develop common principles of legal theory, and to coordinate the efforts of existing academic institutions.

Thirdly, there are legitimate reasons for more active personal participation of scholars in international organizations responsible for the drafting of uniform air law. The more a government is concerned with the practical consequences of international unification of law, the less it seems inclined to entrust its representation at international meetings to independent academic lawyers. This may be natural, as a delegation of obedient civil servants is thought to serve a nation's interests best and to influence an international conference accordingly-but it may be a natural miscalculation. The prewar conferences on uniform private air law, though more or less a European affair, taught an important lesson on international draftsmanship: Germany, then the leading economic power in European civil aviation, regularly appointed delegates to the conferences who-although they were internationally respected for their expert knowledge-were known to be government employees under orders from the Reich Ministries of Justice or Transportation. France, who rảnked only third or fourth in air power, in turn sent delegations headed by Georges Ripert or Albert-Geouffre de La Pradelle, who were known as the great names of the Faculte de Droit of Paris. It is true that they spoke more often for their own French legal minds than for any short-range objectives of the French government; but when they spoke, they carried the floor-CITEJA, diplomatic conferences and all. ${ }^{186}$.

If uniform air law still bears the imprint of French legal thinking today, it is because of scholarly reputation and ability, not because of some sinister European design. As one competent observer of the scene, Otto Riese, later put it: ${ }^{187}$

“Ce n'est pas la puissance ni la grandeur politique

d'un pays, mais la pertinence des idées qui fait triompher les progrès dans l'humanité."

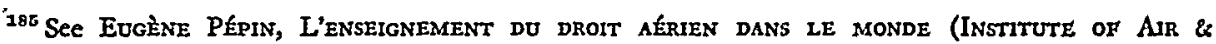
SPACE LAW PUB. No. 5, I958).

${ }^{188}$ Significantly, though, it was easier for powerful states to influence uniform texts passed by IATAto the point where a Dutch court in the 1936 Ooievaar case (supra note 16 ) based its interpretation of the IATA standard conditions on affidavits received from the two German and British airline attorncys who were known as the authors of the conditions.

${ }^{187}$ Riese, Réflexions sur l'unification internationale du droit aérien, sa situation actuelle, ses perspectives, 5 REVUE FRANĢASE DE DROIT AERIEN 131, 148 (I95I).
} 